\title{
Diagnostic and Therapeutic Approaches to Radioactive lodine Refractory Differentiated Thyroid Cancer
}

\author{
Junsun Ryu \\ Head and Neck Oncology Clinic, National Cancer Center, Goyang, Korea
}

\author{
방사성 옥소치료에 내성을 가진 분화 갑상선암의 진단 및 치료적 접근 \\ 류 준 선 \\ 국립암센터 두경부종양클리닉
}

Received May 16, 2012

Accepted May 22, 2012

Address for correspondence

Junsun Ryu, MD

Head and Neck Oncology Clinic,

National Cancer Center,

323 Ilsan-ro, Ilsandong-gu,

Goyang 410-769, Korea

Tel +82-31-920-1684

Fax +82-31-920-1244

E-mail jsryu@ncc.re.kr
Unlike most thyroid cancers which have an excellent prognosis with standard treatments such as surgery and additional radioactive iodine therapy followed by long term TSH suppression, $15-20 \%$ of differentiated thyroid cancers are unresponsive, showing locally aggressive behavior or distant metastasis. It has been reported that the ability of iodine uptake among residual follicular cells is usually impaired in such unresponsive cases. As the general incidence of thyroid cancer increases, the number of this radioactive iodine refractory disease is also increasing. This becomes clinically challenging because iodine-based diagnostic and therapeutic approaches are not applicable anymore. Moreover, other conventional modalities including radiotherapy or cytotoxic chemotherapy is neither effective in this subset of thyroid cancer. So many researches are currently under way to find effective molecular targeted therapies, which will play a role in the treatment of these unresectable and advanced cases. This review discusses the recent research progress regarding the iodine avidity of follicular cells in thyroid cancer, and outcomes of clinical studies using targeted agents.

Korean J Otorhinolaryngol-Head Neck Surg 2012;55:403-9

Key Words Differentiated thyroid cancer - Radioactive iodine refractory ·

Sodium-iodide symporter - Targeted therapy.

\section{서 론}

최근 발표된 국가암 통계에 의하면 갑상선암의 발생은 급격 히 증가하여 2009년 한 해에만 약 31977명의 새로운 환자가 발생하는 것으로 나타나 모든 암종을 통틀어 1위를 차지했다. 이는 우리나라 암발생 환자의 $16.6 \%$ 이자, 인구 10 만명당 108.2 명의 환자에 해당될 정도로 높은 빈도이다. ${ }^{1)}$

알려진 대로 갑상선암은 표준치료인 수술과 방사성 옥소치 료(radioactive iodine treatment), 장기간 TSH 억제치료로 매 우 좋은 예후를 나타낸다. 특히 우리나라 갑상선암은 외국에 비해 분화암, 특히 유두암이 압도적으로 많고, 조기검진 등의 영향으로 $1 \mathrm{~cm}$ 미만의 미세암의 빈도가 높아, 예후가 좋지 않
은 조직형을 포함하더라도 5년 생존율은 99.7\%에 달한다고 보고되었다. ${ }^{1)}$ 이렇게 갑상선암이 예후가 좋은 이유는 천천히 자라는 암종이기 때문이기도 하지만 갑상선세포(follicular cell) 에 대한 효과적인 전신치료인 방사성 동위원소치료(옥소치 료)가 한 몫을 한다.

하지만 높은 생존율과는 별개로 분화암의 15 20\%의 환자 에서는 국소재발이나 원격전이가 발생되멸) 이 중 일부는 progressive, locally aggressive, recurrent metastatic disease의 형태로 나타나 결국 생명을 위협하기에까지 이른다. 최근 갑 상선암의 높은 유병률을 감안할 때 이는 결코 적은 수치가 아 니다. 임상적으로 이러한 양상을 나타내는 환자들 중 상당수 에서는 잔존 갑상선(암)세포의 요오드 섭취능력이 떨어져 있 
어 옥소치료에 대한 내성을 나타내며(nonradioiodine avid) 이전에는 스캔음성-갑상글로불린양성(scan-negative, Tgpositive) 암으로 불리웠다. 일반적으로 방사성 동위원소치료 는 표적이 되는 세포에서 높은 동위원소 섭취(uptake)와 저류 (retention)가 이루어 질 때 높은 방사선에너지가 효과적으로 전 달될 수 있으며 이러한 능력이 떨어져 있을 때는 치료의 효과 가 반감될 수 밖에 없다. 따라서 일반적으로 좋은 예후를 나타 내는 갑상선암과는 다른 하나의 질환군으로서 이해해야 하며 진단 및 치료의 접근을 다르게 해야 한다.

본 논문에서는 이러한 방사성 옥소치료 내성인 갑상선암에 대한 진단, 치료적 접근에 대해 논하고자 하며 옥소치료의 대 상이 되지 않는 수질암, 역형성암을 제외한 분화 갑상선암으로 범위를 한정시켜 다루고자 한다.

\section{옥소치료 내성의 정의와 예후}

최근 시행되고 있는 분화 갑상선암에 대한 여러 임상시험 에서는 방사성 옥소섭취를 나타내지 않거나 옥소치료 후 1 년 이 되기 전에 진행하는 하나 이상의 병변을 가지고 있을 때를 옥소치료 내성(radioiodine refractory disease)으로 정의한다. ${ }^{3)}$ 현재 옥소섭취 내성을 진단하는 검사는 체내 요오드과잉(iodine excess)이 없는 상태에서 시행한 전신스캔만으로 확인이 가능하며 이외에 다른 임상적 표지자는 없다.

옥소치료 내성이 환자의 예후 혹은 생존율에 미치는 악영 향은 뚜렷할 것으로 예상되지만 의외로 내성군을 따로 나누 어 장기간 추적관찰한 자료는 거의 없다. 또한 옥소섭취율은 환자의 나이, 분화도, 전이병변의 크기에 따라 변하기 때문에 대규모 연구가 아니면 통계학적으로 유의한 결과를 내기가 어 렵다. Durante 등 ${ }^{4}$ 은 원격전이가 있는 444명의 분화 갑상선 암 환자들을 장기간 추적관찰한 보고에서 옥소섭취가 감소된 환자들에서 원격전이가 발견된 후의 median survival은 3 6 년, 10 년 생존율은 $3 \%$ 에 불과하다고 보고하였다. 반면에 원 격전이가 있지만 옥소섭취가 정상적으로 되는 군에서는 $48 \%$ 의 상대적으로 높은 10년 생존율을 보였다. Mihailovic 등흐은 77 명의 원격전이가 있는 분화 갑상선암 환자에서 10 년 질병특 이생존율(disease specific survival)을 정상 옥소섭취를 나타 내는(iodine avid) 환자군에서는 $48.31 \%$, 옥소섭취가 감소한 (non-iodine-avid) 환자군에서는 $18.33 \%$ 로 보고하였고, 이런 차이는 45세 이하의 환자에서 뚜렷하게 나타났다. 실제로 이 논문에서는 요오드 섭취능이 생존율에 별 영향을 미치지 않는 다고 결론을 내렸으나 포함된 환자수가 많지 않아 한계를 나 타낸다. 이외에 Ronga 등희의 보고에서도 폐전이가 있는 분화 갑상선암의 10 년 생존율이 옥소섭취가 있는 경우에는 $76 \%$, 없
는 경우에는 $25 \%$ 로 역시 차이가 있음을 보였다.

\section{옥소치료 내성의 기전; 현재까지의 연구들}

요오드는 갑상선호르몬을 만드는 데 필수적인 재료로 쓰이 며 이 과정은 요오드의 섭취(uptake)와 유기화(organification) 로 나뉘어진다(Fig. 1). 소포세포(follicular cell)는 정상적으 로 혈청농도보다 40배 이상의 요오드를 농축시킬 수 있으며 이러한 요오드의 세포내 운반은 기저측막(basolateral membrane)에 위치한 sodium-iodide symporter(NIS)에 의해 능 동적으로 이루어지고 여기에 필요한 sodium의 농도차이는 $\mathrm{Na}^{+} / \mathrm{K}^{+}$ATPase에 의해 유지된다. NIS를 encoding하는 유전 자는 solute carrier family 5A, member 5(SLC5A5)로 19p13 염색체 상에 위치하며 15 개의 exon으로 구성된다.'

갑상선암에서 방사성 옥소내성시 나타나는 요오드 섭취 감 소와 관련하여 NIS, Pendrin, thyroperoxidase, TSH receptor 의 변이 및 양적 변화에 대해 여러 가설이 제시되었고 특히 가 장 중요한 과정으로 생각되는 NIS의 발현에 대해 가장 많은 연구가 이루어져 왔으나, 현재까지는 분화 갑상선암에서 NIS 와 관련된 돌연변이나 유전자변형은 없다고 알려져 있다. ${ }^{8)}$ 대 부분의 연구들은 갑상선암에서 변화하는 NIS protein이나 $\mathrm{mRNA}$ 의 발현정도와 연관된 것들로서 이를 살펴보면 일부 의 보고에서는 NIS의 발현이 갑상선암에서 증가한다는 보고 도 있었으나 ${ }^{9,10)}$ 대부분은 분화 갑상선암에서 정상보다 NIS 발

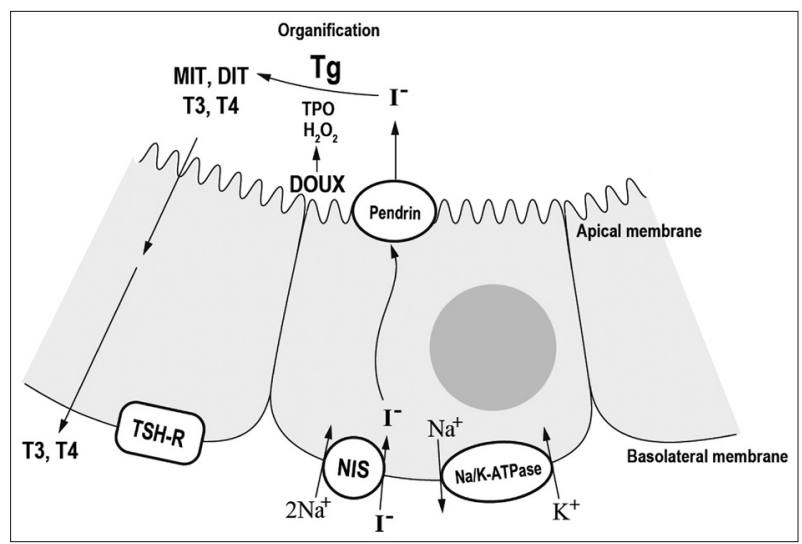

Fig. 1. lodine metabolism in normal follicular cells. NIS in the basolateral membrane takes up iodide from the blood. Pendrin involves in efflux of iodide at the apical membrane into the colloid. lodide is organified in the tyrosil residues of $\mathrm{Tg}$ in a reaction catalyzed by TPO, in the presence of $\mathrm{H}_{2} \mathrm{O}_{2}$, which is produced by DOUX. Tg contains MIT, DIT, T3, and T4 and is stored in the colloid until T3 and T4 need to be released into the blood. TSH signaling via the TSH receptor controls the whole process of thyroid hormone synthesis. NIS: sodium-iodide symporter, TPO: thyroperoxidase, MIT: monoiodotyrosine, DIT: diiodotyrosine, T3: triiodothyronine, T4: thyroxine, DOUX: dual oxidase, TSH-R: TSH receptor. 
현이 감소함을 보였다. ${ }^{11-13)}$ 이러한 결과들의 차이는 갑상선암 에서는 기저측막에 있는 NIS가 세포질 내로 이동(relocalization)하여 발현이 많이 되더라도 기능을 못하게 된다는 것으 로 설명한다. ${ }^{13,14)}$ 반면 NIS mRNA는 거의 모든 연구에서 감 소하는 것으로 나타났다. 하지만 mRNA와 단백질의 발현은 연관성이 나타나지 않았으며 ${ }^{15-17)}$ 이는 NIS와 관련하여 아직 밝 혀지지 않은 transcriptional, post-transcriptional factor들 이 존재함을 의미한다. 또한 임상적으로는 전이부위와 원발 부위에서의 NIS 발현이 다른 경우가 많암,19) NIS 발현 자체 는 옥소치료 내성에 대한 진단적 표지자, 혹은 예후인자가 되 는 데는 부족하다는 것이 현재까지의 결론이다.

옥소섭취의 감소는 병의 진행과정 중에 나타나는 경우가 많 으며 많은 연구자들은 이것을 역분화(de differentiation, loss of differentiation) 과정이라고 보고 있다. 또한 암세포에서는 증가되는 포도당의 섭취에 중요한 단백질인 glucose transporter 1(GLUT-1)의 발현이 증가되며 이는 분화도가 나빠질 수록 그 정도가 크다고 알려져 있다. 갑상선암에서도 이 GLUT-1 의 발현 증가가 NIS의 발현 감소와 동시에 일어나 공격적인 임 상양상을 나타내게 되며 이는 잘 알려진 ${ }^{131} \mathrm{I}$ scan과 ${ }^{18} \mathrm{FDG}-$ PET의 역상관관계인 flip-flop phenomenon을 설명한다. ${ }^{20)}$ Grabellus 등른 최근의 보고에서 갑상선암의 분화도가 나빠 짐에 따라 나타나는 이러한 현상을 ${ }^{18} \mathrm{FDG}$ 와 ${ }^{124} \mathrm{I} \mathrm{PET} / \mathrm{CT}$ 에 서 비교하여 증명하였다. 또한 그는 GLUT1이 MAPK pathway의 target이기도 하므로 갑상선암에서 흔히 발견되는 braf mutation에 의해 이러한 현상들이 유발될 수 있다고 주장하 였다. ${ }^{22)}$ 또한 최근 연구들에서는 옥소치료 내성 갑상선암에서 는 잘 알려진 RET/PTC 재배열, braf 돌연변이, ras 돌연변이 이외에 PI3K/AKT/mTOR pathway에 추가적인 돌연변이를 가지고 있다는 보고들이 나오고 있으나 좀더 연구가 필요한 실정이다. ${ }^{23,24)}$

옥소치료 내성을 가진 환자에서의 중요한 치료전략 중 하 나는 NIS의 발현을 늘려 옥소치료의 감수성을 높이고자 하 는 것이다. 과거로부터 여러 연구들이 있었으며 retinoic acid, rexinoids, PPAR $\gamma$ agonist인 rosiglitazone, histone deacetylase (HDAC) inhibitor들은 전임상에서는 좋은 결과를 나타내었으 나 실제 임상에서는 좋은 결과를 만들어내지 못했다. 최근에 는 표적치료제인 Sorafenib, Sunitinib, Selumetinib 등도 이러 한 의미로 시도되었으나 실제 환자에서 효과를 증명하는 데에 는 실패했다. ${ }^{25,26)}$ 따라서 NIS의 인위적인 발현증가 만으로는 갑상선암에 존재하는 여러 대사이상을 교정하기는 힘들다는 것이 현재까지의 결론이다.

\section{옥소치료 내성환자에서의 재발 및 전이의 진단}

초치료를 마친 환자에서 $\mathrm{Tg}$ 나 $\mathrm{Tg}$ 항체가 증가해 있고 음성 스캔을 나타낸다면 옥소섭취를 하지 않는(non-radioiodine avid) 잔존암이나 국소 및 원격 재발병변을 시사하는 소견이 다. 이때는 전신스캔의 민감도가 떨어져 있으므로 non radioiodide imaging인 초음파나 CT, MRI, PET-CT 등을 시행해 야 한다.

초음파는 매우 민감한 검사로 특히 상당수의 초기 재발병변 에서는 요오드의 섭취가 정상이더라도 음성스캔과 undetectable Tg로 나타날 수 있으므로 옥소치료내성환자뿐 아니라 모 든 환자의 추적관찰 검사에 포함시켜야 한다. ${ }^{27)}$ 게다가 대부분 의 재발은 경부에서 가장 먼저 나타나므로 더 의미가 있다. 경 부의 림프절 재발이 의심될 때는 세침검사시 washout $\mathrm{Tg}$ 를 함 께 검사함으로써 진단율을 높일 수 있다.

$\mathrm{CT}, \mathrm{MRI}$ 는 초음파만큼 민감도가 높지는 않지만 재발림프 절이 초음파로는 발견이 어려운 경부 깊숙이 존재할 때나 $\mathrm{Tg}$ 가 상승시 가장 원격전이가 많은 부위인 폐의 검사에 유용하 다. 이외에 환자의 증상에 따라 뇌, 척추, 복부, 골반 등의 검사 도 고려한다.

PET-CT는 갑상선암에서는 민감도 특이도가 높지는 않지 만 내성환자에서 옥소섭취와 역 상관관계를 보이고, 역분화 (dedifferentiation)를 대별한다고 알려져 있으므로 유용하게 쓰일 수 있다. 특히 잠복전이(occult metastatis)나 재발 및 전 이의 발견 뿐 아니라 병변의 SUV 값으로 환자의 예후까지도 예측할 수 있다는 보고도 나오고 있다. ${ }^{28)}$ 또한 특이하게도 TSH stimulation에 의해 요오드와 마찬가지로 $\mathrm{FDG}$ 의 섭취도 증 가하는 것으로 알려져 있다. ${ }^{29)}$

이렇게 잔존 갑상선암세포가 옥소섭취를 하지 않는다면 전 신스캔의 역할이 많이 떨어지고 다른 진단법들을 고려해야 한다. 추적관찰 중 이러한 영상진단에서 병변이 관찰되면 6개 월마다 반복하여 Response to Treatment in Solid Tumors (RECIST) 기준에 따라 진행 정도를 평가하는 것이 권장되고 있다. ${ }^{30)}$

\section{옥소치료 내성환자에 대한 치료적인 시도들}

Durante 등 ${ }^{4}$ 의 보고에 의하면 분화 갑상선암의 $10 \%$ 이하 에서 원격전이가 있고 이 중 반수 정도는 초진시 발견된다. 원 격전이의 위치는 폐가 $50 \%$ 로 가장 흔하고, 뼈전이가 $25 \%$, 폐 와 빼전이가 함께 있는 경우가 $20 \%$ 로 보고되었다. 
Table 1. Selection of metastatic thyroid cancer patients for therapy ${ }^{3)}$

Candidates for radioiodine treatment

Younger age

Well-differentiated papillary and follicular thyroid tumor

High radioiodine uptake in the metastases

Small metastases

Location in lungs

Apparently stable or slowly progressive disease

Low uptake of FDG

Candidates for other treatment modalities

Older age

Poorly differentiated thyroid tumor

No or low radioiodine uptake

Large metastases

Location in bones

Rapidly progressive disease

High uptake of FDG

Refractory to radioiodine treatment: patients who have at least one lesion without radioiodine uptake or that has progressed within a year following radioiodine treatment; cases of progression should be considered candidates for therapeutic trials

원격전이가 있을 때는 TSH suppression과 함께 수술, 방사 선 치료 및 radiofrequency ablation 등의 적절한 국소치료와 함께 전이부위에 요오드 섭취가 있는 경우 방사성옥소치료를 추가한다. ${ }^{31)}$ 옥소치료의 반복이 효과가 있는 경우는 $85 \%$ 정도 로서 이 중 $96 \%$ 에서는 $600 \mathrm{mCi}$ 의 누적 치료용량 이전에 완전 관해를 나타낸다. ${ }^{3)}$ 하지만 옥소치료내성이 있거나 $600 \mathrm{mCi}$ 이 상의 누적용량의 치료 후에도 지속되는 병변이 있는 환자에서 는 국소치료 후 시행하는 옥소치료는 효과가 없을 뿐더러 ${ }^{32}$ 구강건조증, 비루관폐쇄(nasolacrimal duct obstruction), 이차 원발암(secondary malignancy) 등 부작용의 빈도만 올리게 된다. ${ }^{33,34)}$ 이렇게 옥소치료가 여의치 않을 때는 부위에 따라 수술 등 국소치료를 반복하거나 doxorubicin 등 세포독성 항 암제의 투여를 고려할 수도 있으나, 그 효과는 0 22\%에 불과 하다. ${ }^{3)}$

실제 임상에서 가장 문제가 되는 환자는 이렇게 옥소치료 내성이 있으면서 수술로 절제가 불가능한 진행성 병변을 가지 고 있는 경우로서, 최근에는 중추신경계를 제외한 부위는 표 적치료제 등 임상시험을 고려할 수 있다. ${ }^{35)}$ 원격전이가 있는 환자에서 옥소치료를 할지 임상시험을 시행할지에 대한 일반 적인 분류기준은 Table 1과 같다. 만일 기준에 합당하지 않은 경우에는 상업적으로 구입이 가능한 표적치료제인 pazopanib, sorafenib, sunitinib 등의 off-label 투여를 고려할 수도 있다.

최근 분자생물학의 발전에 따라 많은 표적치료제에 대한 임상시험들이 시행되고 있으며 각 임상시험의 환자포함 기준 은 약간씩 차이가 나나 RECIST 등 표준 반응척도(response criteria)를 사용한 객관적인 효과판정을 하고 수질암, 역형성
Table 2. Targeted agent currently being used in clinical trials and their targets

\begin{tabular}{ll}
\hline \multicolumn{1}{c}{ Drug } & \multicolumn{1}{c}{ Targeted Tyrosine Kinases } \\
\hline Motesanib & VEGFR1-3, PDGFR, c-Kit, RET \\
Axitinib & VEGFR1-3, PDGFR, c-Kit \\
Sorafenib & VEGFR1-3, PDGFR, RET, RAF, C-Kit \\
Sunitinib & PDGFR, VEGFR1-3, c-Kit, RET, CSF1R, FLT3 \\
Pazopanib & VEGFR, PDGFR, c-Kit \\
Lenvatinib & VEGFR1-3, FGFR1-4, RET, C-Kit, PDGFR \\
Cabozanitinib & HGFR, VEGFR2, RET \\
\hline
\end{tabular}

암을 제외한 분화 갑상선암 만으로 대규모의 다기관 2상, 3상 연구들이 진행 중이며 조만간 좋은 결과가 나올 것으로 기대 된다. 한편 이러한 표적치료제는 지금까지는 일찍 시작하면 좋 다는 근거가 없으므로 증상이 없을 때는 고려하지 않는다. ${ }^{35)}$ 지금까지 갑상선암의 임상시험에서 사용되었던 표적치료제 와 그 target들을 보면 VEGFR 등 antiangiogenic therapy가 주를 이루고 있다(Table 2).

분화 갑상선암에서 2상 이상의 결과에 대한 보고는 다음 과 같다. 또한 아직 보고되지는 않았으나 현재 Sorafenib, Axitinib, Lenvatinib에 대한 3상 연구들이 진행 중이다.

\section{Motesanib}

2005년도에 갑상선암에서는 처음으로 2상을 시작한 약제로 이 임상실험에서는 93명의 환자를 대상으로 하였다. 투여 후 $14 \%$ 의 환자에서 부분관해(partial response, PR), $35 \%$ 의 환자 에서 24주 이상의 안정병변(stable disease, SD)을 나타냈고 무 진행생존율의 중앙값(median progression free survival, PFS) 은 40주였다. Braf 억제효과는 없는 약제이지만 braf 돌연변 이가 있는 경우에 더 효과가 좋았다. 이는 braf 돌연변이가 있 는 종양이 VEGF에 의한 혈관신생에 더 의존성이 있음을 시 사한다. 부작용은 설사, 혈압상승, 피로 등이었으며 2명의 환자 가 치료와 연관된 폐출혈로 사망하였다. ${ }^{36)}$ 혈청 $\mathrm{Tg}$ 는 $45 \%$ 의 환자에서 $50 \%$ 이상 감소하였으며 이는 영상검사상의 반응과 연관이 있었다.

91명의 수질암 환자를 추가하여 함께 분석한 biomarker study에서는 치료 중 placental growth factor와 soluble VEGFR2의 농도는 best tumor response와 연관이 있었다. ${ }^{37)}$

\section{Axitinib}

45명의 환자를 대상으로 하였으며 대상환자 중에는 이전에 항암치료를 받은 환자가 많이 포함되어 있었다. ${ }^{38)} 31 \%$ 의 환자 에서 투여 후 PR을 나타냈으며 median PFS는 18개월이었다. 부작용은 혈압상승, 구내염, 피로, 설사 등이었으며 일부의 환 자에서 측정된 혈청 $\mathrm{Tg}$ 는 영상검사상의 반응과는 상관관계가 
없었고 환자수가 적어 biomarker로서의 의미는 알 수가 없다. 현재 추가적으로 doxorubicin 내성을 가진 환자군에 대하여 clinical trial이 진행 중이다.

\section{Sorafenib}

가장 많이 연구된 약으로 상업적으로 구입이 가능하다. 원 래는 간세포암에서 사용되는 약제로서 갑상선암에서는 in vitro study에서 큰 효과를 보여 임상시험에 도입되었다. 첫 번째 2상 시험은 41명의 원격전이가 있는 유두암에 대해 시행 되었으며 $15 \%$ 의 환자에서 $\mathrm{PR}$ 을 나타내었고 $56 \%$ 의 환자에서 6개월 이상의 $\mathrm{SD}$ 를 보였으며 median PFS는 15 개월로 나타 났다. 흔한 부작용은 hand-foot mouth syndrome과 근육통, 피로 등이었다. ${ }^{39)}$

30 명의 원격전이가 있는 환자들을 대상으로 한 두 번째 2 상 시험에서는 투여 후 23\%의 환자에서 PR, 53\%에서 14 89 주 동안 $\mathrm{SD}$, median PFS는 84주였다. 혈청 $\mathrm{Tg}$ 는 대부분의 환 자에서 평균 70\% 이상 감소하였으나 반응의 정도와는 관계가 없었다. 이 중 한명의 환자가 간독성으로 사망하였다. ${ }^{40)}$

최근의 Hoftijzer 등 ${ }^{25)}$ 에 의해 발표된 다른 임상시험은 31명 의 metastatic or locally advanced 환자를 대상으로 하였으며 PR 25\%, SD 34\%, median PFS는 58주로 나타났고 뼈전이가 있는 환자에서는 효과가 덜하였다. 특히 이 논문에서는 치료 26 주 후에 전신스캔을 시행하여 방사성 옥소섭취가 다시 유 도되는지를 보았으나 효과가 없었다.

Sorafenib에 대해서는 현재 double-blind, randomized placebo-controlled phase III DECISION(StuDy of SorafEnib in LoCally Advanced or MetastatIc PatientS with RAI-RefractOry Thyroid CaNcer) trial이 진행되고 있다. ${ }^{41)}$

\section{Pazopanib}

39 명의 옥소치료 내성의 진행병변을 가진 분화 갑상선암 에 대해 $49 \%$ 의 환자에서 PR을 나타냈으며 median PFS는 11.7 개월이었다. 이 중 $88 \%$ 의 환자에서 serum $\mathrm{Tg}$ 가 적어도 $30 \%$ 이상 감소하였다. 또한 첫번째 투여 후의 pazopanib의 혈장 농도가 영상검사상 반응(radiologic response)과 상관관 계가 있었다. 용량제한(dose limiting)의 부작용은 피로, 피부와 모발의 착색, 설사, 오심 등이었다. ${ }^{42)}$

\section{Sunitinib}

28명의 원격전이가 있는 옥소치료 내성, FDG-PET avidity 를 가진 환자 중 $28 \%$ 에서 효과를 나타냈으며 이 중 상당수의 환 자에서 치료 7일 후에 PET-CT 상 SUV가 줄어든 것을 확인하 였으며 초기에 효과가 없는 환자들을 배제시키는 response pre- dictor의 역할을 기대하고 있다. ${ }^{43}$

\section{Lenvatinib; E7080}

2상 임상연구에서 58 명의 옥소치료 내성을 가진 분화 갑상 선암 환자에서 PR 50\%, SD 45\%로 무려 95\%의 높은 임상적 이득(clinical benefit) 혹은 disease control rate을 나타냈으 며, median PFS는 13.3개월이었다. 치료부작용은 혈압상승, 단백뇨, 체중감소, 설사 등이었으며 ras 돌연변이가 있는 경우 에 더 좋은 효과를 나타내었다. 현재 3상 다기관 randomized, placebo controlled study가 진행중이다. ${ }^{44)}$

\section{Selumetinib; AZD6224}

가장 최근에 발표된 결과로 기존의 angiogenesis가 아닌 MAPK pathway 중 MEK를 억제하는 약제에 대한 최초의 보 고이다. 임상적 이득(clinical benefit)은 $57 \%(\mathrm{CR}+\mathrm{PR}+\mathrm{SD})$ 로 약간 실망스러운 결과를 보였고 기대했던 요오드섭취의 증가 효과도 미미하였다. 하지만 braf mutation이 있는 경우에 더 좋 은 효과를 나타낸 것으로 보여 좀더 연구가 필요할 것으로 보 인다. ${ }^{45)}$

\section{결 론}

일반적으로 좋은 예후를 나타내는 분화 갑상선암에서 일 부의 환자들은 옥소섭취의 감소를 보이며 재발, 원격전이 등 의 좋지 않은 경과를 나타낸다. 이같은 요오드 흡수 감소기 전에 대하여 많은 연구가 진행되었으나 아직은 명확한 원인이 밝혀지지 않았고 이와 관련하여 임상적으로 쓰일 수 있는 표지 자나 target도 현재까지는 없는 형편이다.

한편 옥소치료 내성 갑상선암은 요오드를 기반으로 한 기존 의 진단과 치료를 적용시키기가 힘들다. 진단에 있어서는 초음 파를 비롯한 CT, MRI 등 non iodine modality를 사용하여야 하며 치료에 있어서도 누적용량 $600 \mathrm{mCi}$ 이상의 옥소치료를 반복하는 것은 의미가 없다는 것이 최근의 경향이다.

수술 등 기존의 국소치료가 여의치 않고 계속 진행하는 병변 의 경우에는 표적치료제를 이용한 임상시험을 고려해야 한다. 현재 여러 약제들이 시도되고 있고 대부분은 혈관신생과 관련 된 multiple kinase receptor inhibitor들이다. 임상실험된 표 적치료 중에는 상당히 의미있는 효과를 나타내는 것도 있으나 대부분의 병변은 일정기간 후 다시 진행하게 된다. 이는 다른 경로가 존재하던가 내성이 생긴다는 것을 의미한다. 이러한 문 제들을 해결하기 위해 앞으로 나아가야 할 방향을 몇 가지 제 시하면 다음과 같다. 첫째는 독성을 줄이고 여러 pathway를 targeting 할 수 있는 병합요법(combination treatment)의 개발 
이다. 둘째는 유전자 변이의 형태가 다른 각각의 환자군을 나 누어 약제의 선택을 최적화해야 한다는 것이다(customized therapy). 또한 현재 주로 쓰이고 있는 비특이적인 target인 혈관신생 뿐 아니라 갑상선암에서 특이한 유전자이상을 표적 으로 하는 전임상에서 효과가 있었던 약제에 대한 임상실험 을 진행해야 할 것이다.

\section{REFERENCES}

1) National Cancer Center, Ministry of Health \& Welfare. Cancer Facts \& Figures 2011 in the Republic of Korea. Seoul, Republic of Korea; 2011. p.6-21.

2) Eustatia-Rutten CF, Corssmit EP, Biermasz NR, Pereira AM, Romijn JA, Smit JW. Survival and death causes in differentiated thyroid carcinoma. J Clin Endocrinol Metab 2006;91(1):313-9.

3) Schlumberger M, Sherman SI. Clinical trials for progressive differentiated thyroid cancer: patient selection, study design, and recent advances. Thyroid 2009;19(12):1393-400.

4) Durante C, Haddy N, Baudin E, Leboulleux S, Hartl D, Travagli JP, et al. Long-term outcome of 444 patients with distant metastases from papillary and follicular thyroid carcinoma: benefits and limits of radioiodine therapy. J Clin Endocrinol Metab 2006;91(8):2892-9.

5) Mihailovic J, Stefanovic L, Malesevic M, Markoski B. The importance of age over radioiodine avidity as a prognostic factor in differentiated thyroid carcinoma with distant metastases. Thyroid 2009;19(3):227-32. 6) Ronga G, Filesi M, Montesano T, Di Nicola AD, Pace C, Travascio L, et al. Lung metastases from differentiated thyroid carcinoma. A 40 years' experience. Q J Nucl Med Mol Imaging 2004;48(1):12-9.

7) Nikiforov YE, Biddinger PW, Thompson LD. Diagnostic pathology and molecular genetics of the thyroid. 1st ed. Philadelphia, USA: Lippincott Williams \& Wilkins;2009. p.29.

8) Russo D, Manole D, Arturi F, Suarez HG, Schlumberger M, Filetti S, et al. Absence of sodium/iodide symporter gene mutations in differentiated human thyroid carcinomas. Thyroid 2001;11(1):37-9.

9) Wapnir IL, van de Rijn M, Nowels K, Amenta PS, Walton K, Montgomery K, et al. Immunohistochemical profile of the sodium/ iodide symporter in thyroid, breast, and other carcinomas using high density tissue microarrays and conventional sections. J Clin Endocrinol Metab 2003;88(4):1880-8.

10) Wang ZF, Liu QJ, Liao SQ, Yang R, Ge T, He X, et al. Expression and correlation of sodium/iodide symporter and thyroid stimulating hormone receptor in human thyroid carcinoma. Tumori 2011;97(4):540-6. 11) Caillou B, Troalen F, Baudin E, Talbot M, Filetti S, Schlumberger $\mathrm{M}$, et al. Na+/I- symporter distribution in human thyroid tissues: an immunohistochemical study. J Clin Endocrinol Metab 1998;83(11): 4102-6.

12) Faggiano A, Caillou B, Lacroix L, Talbot M, Filetti S, Bidart JM, et al. Functional characterization of human thyroid tissue with immunohistochemistry. Thyroid 2007;17(3):203-11.

13) Morari EC, Marcello MA, Guilhen AC, Cunha LL, Latuff P, Soares FA, et al. Use of sodium iodide symporter expression in differentiated thyroid carcinomas. Clin Endocrinol (Oxf) 2011;75(2):247-54.

14) Smith VE, Read ML, Turnell AS, Watkins RJ, Watkinson JC, Lewy $\mathrm{GD}$, et al. A novel mechanism of sodium iodide symporter repression in differentiated thyroid cancer. J Cell Sci 2009;122(Pt 18):3393-402.

15) Sodré AK, Rubio IG, Galrão AL, Knobel M, Tomimori EK, Alves VA, et al. Association of low sodium-iodide symporter messenger ribonucleic acid expression in malignant thyroid nodules with increased intracellular protein staining. J Clin Endocrinol Metab 2008;93(10): $4141-5$.

16) Trouttet-Masson S, Selmi-Ruby S, Bernier-Valentin F, Porra V, Berger-Dutrieux N, Decaussin M, et al. Evidence for transcriptional and posttranscriptional alterations of the sodium/iodide symporter expression in hypofunctioning benign and malignant thyroid tumors. Am J Pathol 2004;165(1):25-34.

17) Neumann S, Schuchardt K, Reske A, Reske A, Emmrich P, Paschke $\mathrm{R}$. Lack of correlation for sodium iodide symporter mRNA and protein expression and analysis of sodium iodide symporter promoter methylation in benign cold thyroid nodules. Thyroid 2004;14(2):99-111.

18) Castro MR, Bergert ER, Goellner JR, Hay ID, Morris JC. Immunohistochemical analysis of sodium iodide symporter expression in metastatic differentiated thyroid cancer: correlation with radioiodine uptake. J Clin Endocrinol Metab 2001;86(11):5627-32.

19) Min JJ, Chung JK, Lee YJ, Jeong JM, Lee DS, Jang JJ, et al. Relationship between expression of the sodium/iodide symporter and 131I uptake in recurrent lesions of differentiated thyroid carcinoma. Eur J Nucl Med 2001;28(5):639-45.

20) Feine U, Lietzenmayer R, Hanke JP, Held J, Wöhrle H, MüllerSchauenburg W. Fluorine-18-FDG and iodine-131-iodide uptake in thyroid cancer. J Nucl Med 1996;37(9):1468-72.

21) Grabellus F, Nagarajah J, Bockisch A, Schmid KW, Sheu SY. Glucose transporter 1 expression, tumor proliferation, and iodine/glucose uptake in thyroid cancer with emphasis on poorly differentiated thyroid carcinoma. Clin Nucl Med 2012;37(2):121-7.

22) Grabellus F, Worm K, Schmid KW, Sheu SY. The BRAF V600E mutation in papillary thyroid carcinoma is associated with glucose transporter 1 overexpression. Thyroid 2012;22(4):377-82.

23) Ricarte-Filho JC, Ryder M, Chitale DA, Rivera M, Heguy A, Ladanyi M, et al. Mutational profile of advanced primary and metastatic radioactive iodine-refractory thyroid cancers reveals distinct pathogenetic roles for BRAF, PIK3CA, and AKT1. Cancer Res 2009;69(11):4885-93. 24) Saji M, Ringel MD. The PI3K-Akt-mTOR pathway in initiation and progression of thyroid tumors. Mol Cell Endocrinol 2010;321(1):20-8.

25) Hoftijzer H, Heemstra KA, Morreau H, Stokkel MP, Corssmit EP, Gelderblom $\mathrm{H}$, et al. Beneficial effects of sorafenib on tumor progression, but not on radioiodine uptake, in patients with differentiated thyroid carcinoma. Eur J Endocrinol 2009;161(6):923-31.

26) Fenton MS, Marion KM, Salem AK, Hogen R, Naeim F, Hershman JM. Sunitinib inhibits MEK/ERK and SAPK/JNK pathways and increases sodium/iodide symporter expression in papillary thyroid cancer. Thyroid 2010;20(9):965-74.

27) Bachelot A, Leboulleux S, Baudin E, Hartl DM, Caillou B, Travagli JP, et al. Neck recurrence from thyroid carcinoma: serum thyroglobulin and high-dose total body scan are not reliable criteria for cure after radioiodine treatment. Clin Endocrinol (Oxf) 2005;62(3):376-9.

28) Robbins RJ, Wan Q, Grewal RK, Reibke R, Gonen M, Strauss HW, et al. Real-time prognosis for metastatic thyroid carcinoma based on 2-[18F]fluoro-2-deoxy-D-glucose-positron emission tomography scanning. J Clin Endocrinol Metab 2006;91(2):498-505.

29) Moog F, Linke R, Manthey N, Tiling R, Knesewitsch P, Tatsch K, et al. Influence of thyroid-stimulating hormone levels on uptake of FDG in recurrent and metastatic differentiated thyroid carcinoma. J Nucl Med 2000;41(12):1989-95.

30) Eisenhauer EA, Therasse P, Bogaerts J, Schwartz LH, Sargent D, Ford R, et al. New response evaluation criteria in solid tumours: revised RECIST guideline (version 1.1). Eur J Cancer 2009;45(2):228-47.

31) National Comprehensive Cancer Network - Thyroid Carcinoma. version 2. 2012. Available from: URL: http://nccn.org.

32) Pacini F, Agate L, Elisei R, Capezzone M, Ceccarelli C, Lippi F, et al. Outcome of differentiated thyroid cancer with detectable serum $\mathrm{Tg}$ and negative diagnostic (131)I whole body scan: comparison of patients treated with high (131)I activities versus untreated patients. J Clin Endocrinol Metab 2001;86(9):4092-7.

33) Sawka AM, Thabane L, Parlea L, Ibrahim-Zada I, Tsang RW, Brierley JD, et al. Second primary malignancy risk after radioactive iodine treatment for thyroid cancer: a systematic review and meta- 
analysis. Thyroid 2009;19(5):451-7.

34) Shepler TR, Sherman SI, Faustina MM, Busaidy NL, Ahmadi MA, Esmaeli B. Nasolacrimal duct obstruction associated with radioactive iodine therapy for thyroid carcinoma. Ophthal Plast Reconstr Surg 2003; 19(6):479-81.

35) Schlumberger M, Sherman SI. Approach to the patient with advanced differentiated thyroid cancer. Eur J Endocrinol 2012;166(1):5-11. 36) Sherman SI, Wirth LJ, Droz JP, Hofmann M, Bastholt L, Martins RG, et al. Motesanib diphosphate in progressive differentiated thyroid cancer. N Engl J Med 2008;359(1):31-42.

37) Bass MB, Sherman SI, Schlumberger MJ, Davis MT, Kivman L, Khoo HM, et al. Biomarkers as predictors of response to treatment with motesanib in patients with progressive advanced thyroid cancer. J Clin Endocrinol Metab 2010;95(11):5018-27.

38) Cohen EE, Rosen LS, Vokes EE, Kies MS, Forastiere AA, Worden FP, et al. Axitinib is an active treatment for all histologic subtypes of advanced thyroid cancer: results from a phase II study. J Clin Oncol 2008; 26(29):4708-13.

39) Kloos RT, Ringel MD, Knopp MV, Hall NC, King M, Stevens R, et al. Phase II trial of sorafenib in metastatic thyroid cancer. J Clin Oncol 2009;27(10):1675-84.

40) Gupta-Abramson V, Troxel AB, Nellore A, Puttaswamy K, Redlinger $\mathrm{M}$, Ransone K, et al. Phase II trial of sorafenib in advanced thyroid cancer. J Clin Oncol 2008;26(29):4714-9.

41) Brose MS, Nutting CM, Sherman SI, Shong YK, Smit JW, Reike G, et al. Rationale and design of decision: a double-blind, randomized, placebo-controlled phase III trial evaluating the efficacy and safety of sorafenib in patients with locally advanced or metastatic radioactive iodine (RAI)-refractory, differentiated thyroid cancer. BMC Cancer 2011;11:349.

42) Bible KC, Suman VJ, Molina JR, Smallridge RC, Maples WJ, Menefee $\mathrm{ME}$, et al. Efficacy of pazopanib in progressive, radioiodine-refractory, metastatic differentiated thyroid cancers: results of a phase 2 consortium study. Lancet Oncol 2010;11(10):962-72.

43) Carr LL, Mankoff DA, Goulart BH, Eaton KD, Capell PT, Kell EM, et al. Phase II study of daily sunitinib in FDG-PET-positive, iodinerefractory differentiated thyroid cancer and metastatic medullary carcinoma of the thyroid with functional imaging correlation. Clin Cancer Res 2010;16(21):5260-8.

44) Sherman SI. ASCO presentation, 2011.

45) Hayes DN, Lucas AS, Tanvetyanon T, Krzyzanowska MK, Chung $\mathrm{CH}$, Murphy BA, et al. Phase II efficacy and pharmacogenomic study of Selumetinib (AZD6244; ARRY-142886) in iodine-131 refractory papillary thyroid carcinoma with or without follicular elements. Clin Cancer Res 2012;18(7):2056-65.

\section{정답 및 해설}

답 1) 골수외 형질세포종(extramedullary plasmacytoma)

2) 다발성 골수종(multiple myeloma); 골수생검, 혈청단백 전기영동 검사, 소변 Bence-Jones 단백검사 등

해 설 진단은 조직검사상 형질세포종에 합당한 소견과 임상적으로 골수외에서 기원하며 전신적인 전이가 없음을 확인하면 골 수외 형질세포종으로 확진할 수 있다. 조직검사상 형질세포의 단일 세포증식이 미세한 세망내피조직 내로 침윤되어 있으 며 세포 분화도는 다양하고 아밀로이드성 물질이 존재할 수도 있다. 다발성 골수종과의 감별을 위해서는 자세한 이학적 검사와 함께 혈액검사, 골수생검, 혈청단백 전기영동 검사, 면역단백 전기영동 검사, 소변 Bence-Jones 단백, 방사선학적 검사 등이 필수적이다. 특히 핵의학 검사 등을 통해 전신의 뼈에 전이 여부를 확인하는 것이 중요하다. 